J. Clin. Chem. Clin. Biochem.

Vol. 17, 1979, pp. 321-324

\title{
Esterolytic Activity of Blood Serum in Infants with Hypertrophic Pyloric Stenosis
}

\author{
By Z. Szafran, J. Nowak, H. Szafran and A. Janik \\ Department of Clinical Biochemistry and Department of Pediatric Surgery, Institute of Paediatrics, Nicholaus \\ Copernicus Academy of Medicine, Kraków, Poland.
}

(Received May 26/November 6, 1978)

\begin{abstract}
Summary: Esterolytic activity of blood serum was determined in infants with hypertrophic pyloric stenosis and in healthy control children. The substrates hydrolyzed mainly by arylesterase (EC. 3.1.1.2), i.e. $p$-nitrophenyl esters of acetic, propionic and butyric acid were used. It was found that in infants with hypertrophic pyloric stenosis the rate of $p$-nitrophenyl propionate hydrolysis was significantly higher than that of the acetate or butyrate. In control group children all three substrates were hydrolysed at similar rates, and these were significantly lower than in infants with hypertrophic pyloric stenosis.
\end{abstract}

\section{Die esterolytische Aktivität des Blutserums bei Säuglingen mit hypertrophischer Pylorusstenose}

Zusammenfassung: Die esterolytische Aktivität des Blutserums von Säuglingen mit hypertrophischer Pylorusstenose und gesunden Kindern wurde bestimmt. Als Substrate, die hauptsächlich durch Arylesterase hydrolysiert werden, wurden $p$-Nitrophenylacetat, $p$-Nitrophenylpropionat und $p$-Nitrophenylbutyrat eingesetzt. Es wurde festgestellt, daß bei Säuglingen mit hypertrophischer Pylorusstenose die Geschwindigkeit der $p$-Nitrophenylpropionat-Hydrolyse signifikant größer als die der zwei übrigen Ester war. Bei Kindern der Kontrollgruppe wurden alle drei Substrate mit ähnlicher, signifikant niedrigerer Geschwindigkeit als bei Säuglingen mit hypertrophischer Pylorusstenose hydrolysiert.

\section{Introduction}

Arylesterase (EC 3.1.1.2) is the main esterolytic enzyme of human serum, with activity towards aromatic esters (1). The physiological role of this enzyme has not been clearly defined because most studies concerning its properties and function were connected with its unique ability to hydrolyze organophosphate compounds (2). Only Pilz \& Hörlein (3) as well as Augustinsson \& Henricson (4) suggested that arylesterase may take part in the intermediate reactions concerned with fatty acid transport in blood.

Infants with hypertrophic pyloric stenosis, especially before surgical treatment, remain in the state of calorieprotein malnutrition. This results, amongst other things, in an elevation of the free fatty acids in the blood, and enhancement of fatty acid transport. It was therefore of interest to determine the esterolytic activity of the blood serum of infants with hypertrophic pyloric stenosis, using the substrates hydrolysed by arylesterase. The determinations were carried out in these children before and following surgical treatment, in order to explore whether the restoration of normal feeding after the operation results in the change of esterolytic activity.

\section{Material and Methods}

17 infants with hypertrophic pyloric stenosis ( 14 boys and 3 girls), of age between 4 and 10 weeks (group I), and 12 infants without this malformation ( 7 boys and 5 girls), age between 3 and 32 weeks (group II), were studied. In children of group I the manifestations of the disease lasted from 1 to 8 weeks, until the operation of pylorotomy was performed. Weight deficiency in these children at the time of admission was between 5 and 35 per cent. Values for the normal weight of Polish children were taken from Górnicki \& Kurniewicz-Witczakowa (5). The data concerning age, sex, duration of the disease and weight deficiency of infants of group I are given in table 1. Pylorotomy was performed according to the procedure of Fredet \& Ramsted as modified by Grob (6), following alleviation of acid-base and electrolyte balance disturbances. None of the infants of group II showed a weight deficiency. When the determinations of esterolytic activity were performed, these children were considered to be healthy.

In infants of group I the determinations of esteroly tic activity were performed three times: immediately after admission, then three days, and seven days after the operation. In children of group II the determinations were carried out only once.

Esterolytic activity was determined by the kinetic modification of the Huggins \& Lapides method (7). The substrates, $p$-nitrophenyl esters of acetic, propionic and $n$-butyric acid were synthesized as described by these authors. The assay mixture contained $0.5 \mathrm{ml}$ of serum diluted $1: 25 \mathrm{v} / \mathrm{v}$ with $0.15 \mathrm{~mol} / \mathrm{l}$ $\mathrm{NaCl}$ solution, and $1.5 \mathrm{ml}$ of $3.3 \mathrm{mmol} / 1$ phosphate buffer, $\mathrm{pH}$ 7.0. This mixture was preincubated for $10 \mathrm{~min}$ at $25^{\circ} \mathrm{C}$, 
Tab. 1. Clinical data of infants with hypertrophic pyloric stenosis

\begin{tabular}{|c|c|c|c|c|c|}
\hline No. & Initials & $\operatorname{sex}$ & $\begin{array}{l}\text { Age } \\
\text { (weeks) }\end{array}$ & $\begin{array}{l}\text { Duration } \\
\text { of } \\
\text { symptoms } \\
\text { (weeks) }\end{array}$ & $\begin{array}{l}\text { Weight } \\
\text { deficiency } \\
\text { s } \\
(\%)\end{array}$ \\
\hline $\begin{array}{l}1 . \\
2 . \\
3 . \\
4 . \\
5 . \\
6 . \\
7 . \\
8 . \\
9 . \\
10 . \\
11 . \\
12 . \\
13 . \\
14 . \\
15 . \\
16 . \\
17 .\end{array}$ & $\begin{array}{l}\text { G.M. } \\
\text { B.J. } \\
\text { L.T. } \\
\text { Sz.S. } \\
\text { S.B. } \\
\text { L.P. } \\
\text { W.D. } \\
\text { S.R. } \\
\text { S.J. } \\
\text { Z.W. } \\
\text { M.W. } \\
\text { Ch.J. } \\
\text { S.Z. } \\
\text { B.K. } \\
\text { J.B. } \\
\text { T.J. } \\
\text { S.M. }\end{array}$ & $\begin{array}{l}9 \\
0 \\
0 \\
0 \\
0 \\
0 \\
9 \\
0 \\
0 \\
0 \\
0 \\
0 \\
0 \\
0 \\
9 \\
0 \\
0\end{array}$ & $\begin{array}{r}10 \\
9 \\
6 \\
6 \\
10 \\
7 \\
8 \\
6 \\
7 \\
6 \\
5 \\
5 \\
7 \\
8 \\
5 \\
4 \\
6\end{array}$ & $\begin{array}{l}8 \\
4 \\
2 \\
3 \\
3 \\
1 \\
4 \\
3 \\
2 \\
3 \\
2 \\
1 \\
5 \\
3 \\
2 \\
1 \\
1\end{array}$ & $\begin{array}{r}35 \\
30 \\
30 \\
28 \\
28 \\
27 \\
25 \\
25 \\
24 \\
20 \\
20 \\
20 \\
18 \\
15 \\
10 \\
5 \\
5\end{array}$ \\
\hline Mean & & & 6.7 & 2.8 & 21.4 \\
\hline
\end{tabular}

whereupon $0.5 \mathrm{ml}$ of substrate solution was added to give a final concentration of $0.1 \mathrm{mmol} / 1$. Stock substrate solution was prepared by dissolving $1 \mathrm{mmol}$ of the ester in $20 \mathrm{ml}$ of methanol. This was diluted $1: 100 \mathrm{v} / \mathrm{v}$ with distilled water to give the working substrate solution. Immediately after the addition of substrate solution to the assay mixture, the increase in absorbance value at $400 \mathrm{~nm}$ was followed during 3 minutes in a Gilford Model 240 recording spectrophotometer, the temperature of cuvette holder being maintained at $25^{\circ} \mathrm{C}$. Inasmuch as the rate of substrate hydrolysis was not strictly linear, the initial rate of enzymatic reaction was estimated by drawing a tangent line to the time curve obtained. Nonenzymatic substrate decomposition was checked by running the reagent blank in parallel. It was negligible at the $\mathrm{pH}$ and substrate concentration used. Esterolytic activity expressed in $\mu \mathrm{kat} / 1$ was calculated from the reaction rate by taking into account the serum dilution factor and molar absorbance coefficient of $p$-nitrophenol at $400 \mathrm{~nm}\left(5.8 \cdot 10^{3} \cdot 1 \cdot \mathrm{mol}^{-1} \cdot \mathrm{cm}^{-1}\right.$ at $\left.\mathrm{pH} 7.0\right)$ and the phosphate buffer concentration.

Low substrate concentrations and a $\mathrm{pH}$ different from the optimal for serum arylesterase determinations (8) were dictated by the relatively low solubility of $p$-nitrophenyl butyrate and the instability of $p$-nitrophenyl esters in alk aline medium.

Student's $t$ test was used to test the significance of differences between the mean values; a probability of 0.05 or lower was taken to indicate statistical significance.

\section{Results}

The results of the determinations of esterolytic activity in the blood serum of infants with hypertrophic pyloric stenosis before and after the operation are presented in figures 1-3. In most infants the rate of enzymatic hydrolysis was the highest with $p$-nitro- " phenyl propionate as substrate. Only in a few cases was the activity towards this substrate similar or lower than towards the two other esters. Despite wide variations of the individual results, the mean value of $p$-nitrophenyl propionate hydrolysis was significantly higher than those for acetate or butyrate. The level of

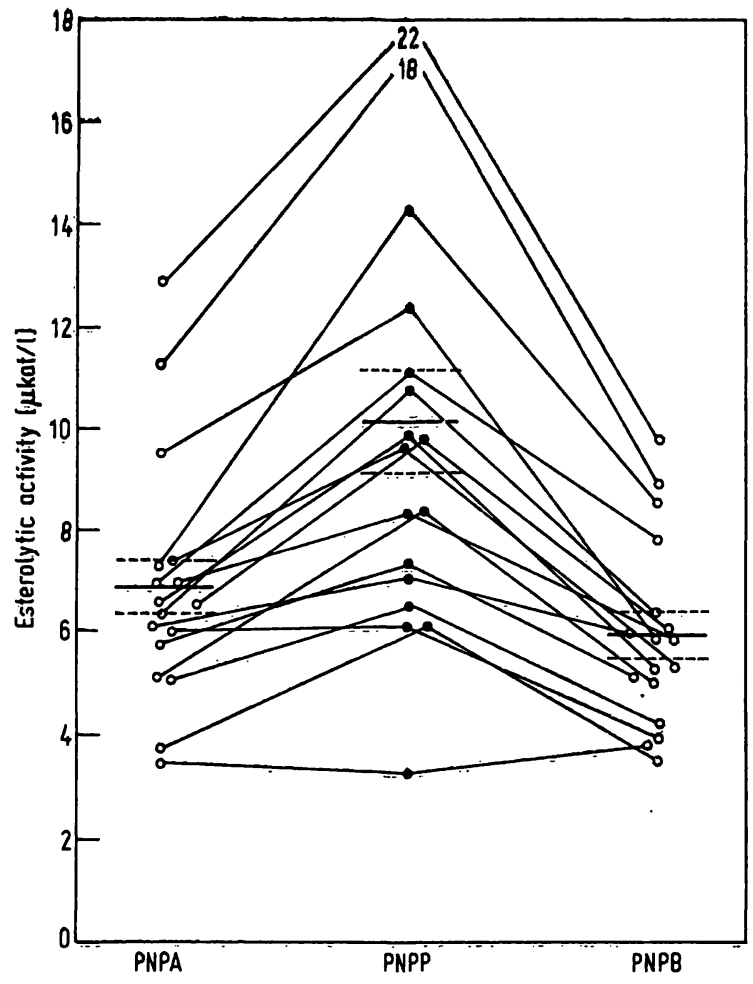

Fig. 1. Esterolytic activity of blood serum of infants with hypertrophic pyloric stenosis, before operation. p-nitrophenyl acetate (PNPA), propionate (PNPP), and butyrate (PNPB) were used as substrates. The results of individual determinations and mean values \pm SEM are given.

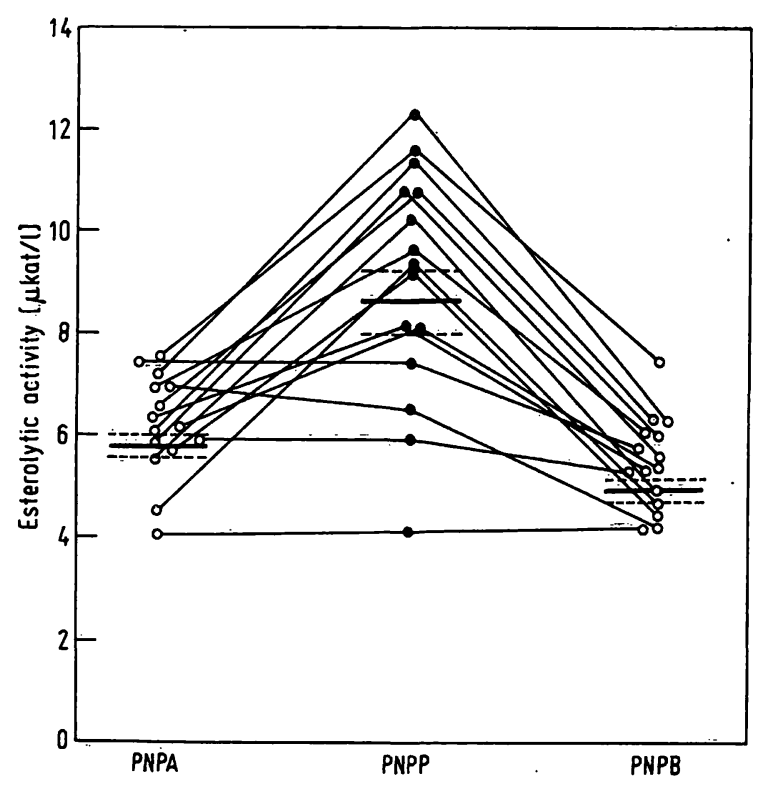

Fig. 2. Esterolytic activity of blood serum of infants with hypertrophic pyloric stenosis, three days after operation. $p$-nitrophenyl acetate (PNPA), propionate (PNPP), and butyrate (PNPB) were used as substrates. The results of individual determinations and mean values \pm SEM are given.

significance was $p<0.02$ and $p<0.005$ for the difference between propionate and acetate, and between propionate and butyrate hydrolysis respectively before the operation; $p<0.001$ for both pairs of substrates 


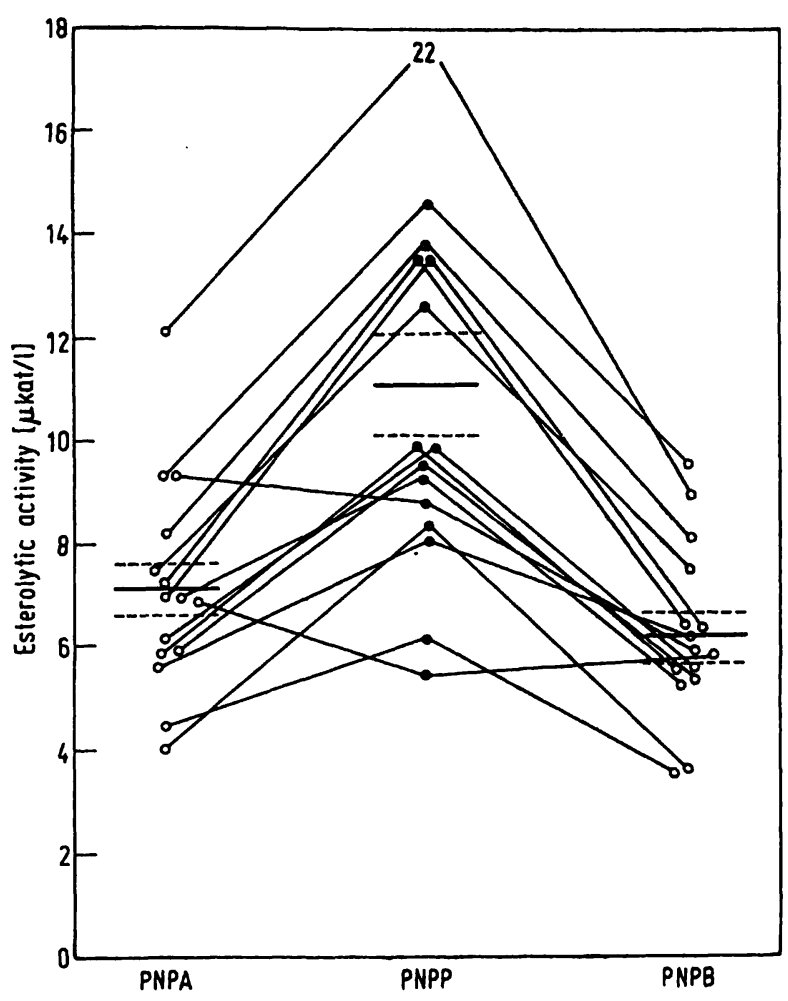

Fig. 3. Esterolytic activity of blood serum of infants with hypertrophic pyloric stenosis, seven days after operation. $p$-nitrophenyl acetate (PNPA), propionate (PNPP), and butyrate (PNPB) were used as substrates. The results of individual determinations and mean values \pm SEM are given.

at the second determination, and $\mathrm{p}<0.001$ and $\mathrm{p}<$ 0.005 at the seventh day after the operation. The mean values for hydrolysis of $p$-nitrophenyl acetate and $p$ nitrophenyl butyrate did not differ significantly. Only in the second determination (third day after the operation, figure 2) was this difference on the verge of significance $\mathrm{p}=0.05$.

Comparing the results obtained before and after the operation, the values were the lowest in the second determination (third day after the operation). Nevertheless, the only statistically significant differences were between the mean values for the second and third determination, using $p$-nitrophenyl propionate $(\mathrm{p}<$ $0.005)$ and $p$-nitrophenyl butyrate $(\mathrm{p}<0.02)$.

Figure 4 presents the results obtained for children of group II. All the three substrates were hydrolyzed at - similar rates, and there were no significant differences between the mean values. On the other hand, the activity values obtained for this group were significantly lower than those obtained for infants with hypertrophic pyloric stenosis in all three determinations, and for all the three substrates used. The level of significance for the differences observed is presented in table 2 .

\section{Discussion}

The results of the present paper demonstrated that the esterolytic activity of blood serum, measured with

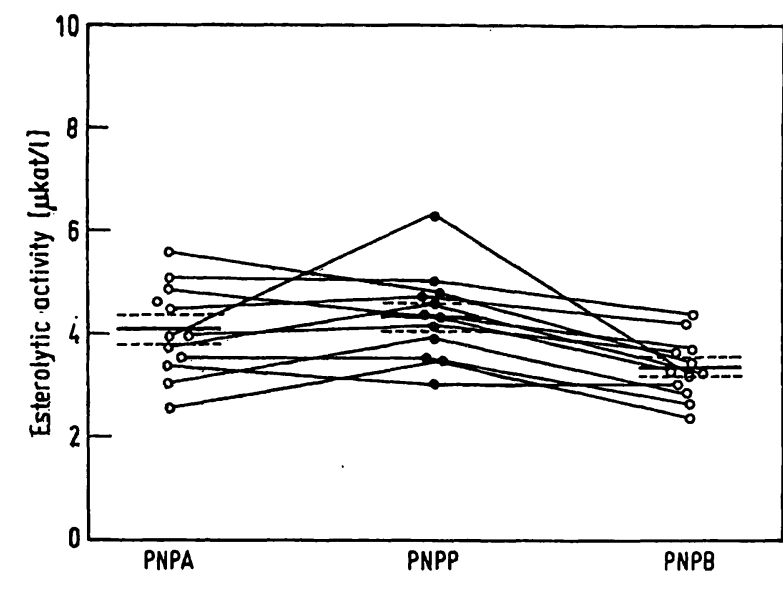

Fig. 4. Esterolytic activity of blood serum of healthy infants. p-nitrophenyl acetate (PNPA), propionate (PNPP), and butyrate (PNPB) were used as substrates. The results of individual determinations and mean values \pm SEM are given.

Tab. 2. Statistical analy sis of differences betwten mean values of blood serum esterolytic activity against $p$-nitrophenyl acetate, propionate and butyrate obtained for the two groups of infants at three stages of treatment.

\begin{tabular}{|c|c|c|c|c|}
\hline & & $\begin{array}{l}\overline{\mathrm{X}}_{1}=\text { group } \\
\text { before } \\
\text { operation } \\
\overline{\mathrm{x}}_{2}=\text { group I }\end{array}$ & $\begin{array}{l}\bar{x}_{1}=\text { group I } \\
3 \text { days after } \\
\text { operation } \\
\bar{x}_{2}=\text { group II }\end{array}$ & $\begin{array}{l}\bar{x}_{1}=\text { group I } \\
7 \text { days after } \\
\text { operation } \\
\bar{x}_{2}=\text { group II }\end{array}$ \\
\hline $\begin{array}{l}p \text {-Nitro- } \\
\text { phenyl } \\
\text { acetate }\end{array}$ & $\begin{array}{l}\bar{x}_{1} \\
\bar{x}_{2} \\
t \\
p<\end{array}$ & $\begin{array}{l}6.80 \\
4.10 \\
3.726 \\
0.001\end{array}$ & $\begin{array}{l}5.68 \\
4.10 \\
4.320 \\
0.001\end{array}$ & $\begin{array}{l}7.09 \\
4.10 \\
4.679 \\
0.001\end{array}$ \\
\hline $\begin{array}{l}\text { p-Nitro- } \\
\text { phenyl- } \\
\text { propionate }\end{array}$ & $\begin{array}{l}\bar{x}_{1} \\
\bar{x}_{2} \\
t \\
p<\end{array}$ & $\begin{array}{l}9.95 \\
4.33 \\
4.110 \\
0.001\end{array}$ & $\begin{array}{l}8.47 \\
4.33 \\
5.898 \\
0.001\end{array}$ & $\begin{array}{l}10.98 \\
4.33 \\
5.510 \\
0.001\end{array}$ \\
\hline $\begin{array}{l}p \text {-Nitro- } \\
\text { phenyl } \\
n \text {-butyrate }\end{array}$ & $\begin{array}{l}\bar{x}_{1} \\
\bar{x}_{2} \\
t \\
p<\end{array}$ & $\begin{array}{l}5.84 \\
3.37 \\
4.495 \\
0.001\end{array}$ & $\begin{array}{l}4.92 \\
3.37 \\
2.365 \\
0.05\end{array}$ & $\begin{array}{l}6.16 \\
3.37 \\
5.471 \\
0.001\end{array}$ \\
\hline
\end{tabular}

three $p$-nitrophenyl esters (acetate, propionate and butyrate), is significantly higher in infants with hypertrophic pyloric stenosis than in children without this malformation.

The two groups of infants differ also in other respect: $p$-nitrophenyl propionate was hydrolyzed at the highest rate in infants with hypertrophic pyloric stenosis, while in healthy children all three substrates were hydrolyzed with similar rates.

Most of the observed activity towards $p$-nitrophenyl esters can be attributed to arylesterase. To prove this wo have tested the effect of E-600 (diethyl-p-nitrophenyl phosphate), a specific inhibitor of B-esterase and cholinesterase, on the hydrolysis of $p$-nitrophenyl esters by human serum. We have found (unpublished data) that tho hydrolysis of $p$-nitrophenyl acetate and $p$-nitrophonyl propionate was not inhibited by $2 \mu \mathrm{mol} / 1$ 
E-600, whereas $p$-nitrophenyl butyrate hydrolysis was inhibited by about 15 per cent.

It has been demonstrated that human serum arylesterase is specific for phenyl acetate, hydrolysing this substrate at a rate 100 times greater than that for phenyl butyrate (1). Of the $\beta$-naphthyl esters, the propionate was hydrolysed at the highest rate (9). Evidently, the substrate specificity of serum arylesterase depends not only on acyl chain length, but also on the type of substituent in the phenyl ring. Apparently, in the case of the $p$-nitrophenyl esters, the propionate is hydrolyzed at the highest rate.

The fact that in children with hypertrophic pyloric stenosis $p$-nitrophenyl propionate hydrolysis proceeds at a significantly higher rate, and in healthy infants only at slightly higher rate than that of acetate or butyrate, seems to indicate the presence in serum of two arylesterase types differing with respect to the substrate specificity; $p$-nitrophenyl acetate being the best substrate for one enzyme, while $p$-nitrophenyl propionate is the best substrate for the other type. In infants with hypertrophic pyloric stenosis, propionatespecific arylesterase appears in a much higher concentration, producing the pattern characterized by a significantly higher rate of $p$-nitrophenyl propionate hydrolysis. The presence in human serum of at least two proteins endowed with arylesterase activity was reported by Wilde \& Kekwick (10) as well as by Skrinjaric-Spoljar \& Reiner (11). The substrate specificity of the two arylesterase species has not, however, been studied.

It is interesting that the high level of esterolytic activity, especially towards $p$-nitrophenyl propionate, in infants with hypertrophic pyloric stenosis, did not change appreciably after the operation. This was true, even at the seventh day when the normal feeding pattern had already been restored. Probably it takes a fairly long time for enzyme synthesis to fall to the normal level. Similarly, Augustinsson \& Henricson (4) observed that in rats starved for some period of time, hydrolysis of phenyl acetate by blood serum was still higher than in control animals several days after resumption of normal feeding. Some decrease in the level of esterolytic activity observed in the third day after the operation was probably caused by the transient limitation of protein synthesis in the liver as a result of surgical trauma. It is not certain, however, whether all esterases appearing in blood plasma are synthesized in the liver. Augustinsson \& Barr (12) suggested that at least one of these proteins is synthesized in the kidney.

A significantly higher activity of arylesterase in the blood serum of infants with hypertrophic pyloric stenosis, with an especially pronounced elevation of $p$-nitrophenyl propionate hydrolysis, can be interpreted as an increase in the synthesis and release to the blood plasma of propionate-specific arylesterase species induced by the metabolic effect of malnutrition. It is a well known fact, that in malnutrition, fatty acids are mobilized from adipose tissue in response to hypoglycaemia and resulting hypoinsulinaemia, then utilized in most tissues as the main source of energy. To provide for the increased demand for fatty acids in metabolizing tissues, the fatty acid transport system must function with a much greater turnover than usual; thus the concentration of all factors participating in this system should be greater. Most probably one of these factors is arylesterase. It has been postulated that plasma arylesterase facilitates the transport of higher fatty acids by catalyzing the exchange between low fatty acids esterified with the tyrosine hydroxyl of plasma proteins and higher fatty acids (9). The hypothesis that assumes the role of arylesterase in fatty acid transport was also confirmed by Augustinsson \& Henricson (4), who observed that the esterolytic activity of blood serum increases in starved rats. The present work, which shows that infants with hypertrophic pyloric stenosis, a disease associated with malnutrition, have a significant increase in the arylesterase activity of their blood serum, provides some additional support for the above hypothesis.

\section{References}

1. Augustinsson, K.-B. (1958), Nature 181, 1786-1789.

2. Aldridge, W.N. \& Reiner, E. (1972), Enzyme Inhibitors as Substrates. North Holland Publishing Company, Amsterdam and London.

3. Pilz, W. \& Hörlein, H. (1964), Hoppe Seyler's Z. Physiol. Chem., 335, 221-228.

4. Augustinsson, K.-B. \& Henricson, B. (1965), Acta Physiol Scand., 64, 418-425.

5. Górnicki, B. \& Kurniewicz-Witczakowa, R. (1972), Vademecum Pediatrii. (B. Górnicki ed.), PZWL Warszawa.

6. Grob, M. (1957), Angeborene hypertrophische Pylorusstenose, Lehrbuch der Kinderchirurgie. Georg Thieme Verlag, Stuttgart

7. Huggins, C. \& Lapides, J. (1947), J. Biol. Chem. 170, 467482.
8. Koch, C.-D., Block, H. \& Molz, J. (1975), Z. Gastroenterol, $13,695-703$.

9. Pilz, W, (1974), Arylesterases, in Methods of Enzymatic Analysis, second edition, (H.:U. Bergmeyer, ed.) Verlag Chemie, Weinheim and Academic Press, New York and London, S. 806-813.

10. Wilde, C. E. \& Kekwick, R. G. O. (1964), Biochem. J. 91, 297-307

11. Skrinjariê-Spoljar, M. \& Reiner, E. (1968), Biochim. Bio= phys. Acta 165, 289-292.

12. Augustinsson, K.-B. \& Barr, M. (1963), Clin. Chim. Acta \&, $568-573$.

Prof. Dr. Z. Szafran

Inst. of Pediatries

ul. Wielicka 265

PL-30:663 Kraków . 


\section{Journal of Clinical Chemistry and Clinical Biochemistry Zeitschrift für Klinische Chemie und Klinische Biochemie}

Gemeinsames Organ der Deutschen, der Österreichischen und der Schweizerischen Gesellschaft für Klinische Chemie

We would like to draw your attention to our special

\section{Reduced Subscription Prices}

available to personal members of national societies of Clinical Chemistry associated with the IFCC (corporative members, such as hospitals, institutes, firms, etc. are strictly excluded from this offer).

Price for members of national Societies of Clinical Chemistry associated with the IFCC

DM 234, ${ }^{*}$ (for 12 issues)

(regular price DM 360,-)

Price for members of the German, the Austrian and the Swiss Society of Clinical Chemistry

$$
\text { DM 90,- (for } 12 \text { issues) }
$$

These orders must be sent directly to the publishers.

Upon receipt of the certificate of membership, which can be obtained from the society's treasurer, the publisher will gladly include the member's name on the subscribers' list.

* Price effective from March 1st, 1979
Wir möchten Sie auf die

Vorzugspreise im Jahresabonnement für persönliche Mitglieder der nationalen Gesellschaften für Klinische Chemie, die der IFCC angeschlossen sind, aufmerksam machen (korporative Mitglieder, wie z. B. Kliniken. Institute, Firmen usw., sind ausdrücklich hiervon ausgeschlossen).

Preis für Mitglieder der nationalen Gesellschaften für Klinische Chemie, die der IFCC angeschlossen sind

DM 234, ${ }^{\star}$ (12 Hefte)

(regulärer Preis DM 360,-)

Preis für Mitglieder der Deutschen, der Österreichischen und der Schweizerischen Gesellschaft für Klinische Chemie

DM 90,- (12 Hefte)

Die Bestellungen sind direkt an den Verlag zu richten.

Die für diesen verbilligten Bezug erforderliche Bescheinigung über die Mitgliedschaft erhalten die Mitglieder vom Schatzmeister der jeweiligen Gesellschaft.

* Preis ab 1. März 1979 


\section{Paperback edition}

\section{H. Ch. Curtius \\ M. Roth \\ (Editors)}

\section{Clinical Biochemistry}

\section{Principles and Methods}

2 volumes. Paperback edition 1978.

$15,5 \mathrm{~cm} \times 23,0 \mathrm{~cm}$. With numerous tables and figures.

Volume I: LXIII, pages 1-854.

DM 105,-; \$49.50 ISBN 3110076691

Volume II: LXIII, pages 855-1677.

DM 105,-; \$49.50 ISBNN 3110076705

61 authors from 11 different countries have contributed to this book which presents many of the techniques of interest to clinical chemists and clinical biochemists.

Current procedures are critically discussed, and special , emphasis is given to new methods likely to become important in the coming years. A number of techniques are given in detail, and the others are presented with the appropriate references.

The book contains numerous tables and illustrations, and an extensive index permits ready access to specific items.

Prices are subject to change without notice 